\title{
PENINGKATAN PERILAKU SADAR PERIODONTAL SEHAT BAGI IBU HAMIL DI MASA PANDEMI COVID-19
}

\section{Komang Evan Wijaksana, Lambang Bargowo, Shafira Kurnia Supandi}

Departemen Periodonsia, Fakultas Kedokteran Gigi Universitas Airlangga, Surabaya

i.komang.evan.w@fkg.unair.ac.id

\begin{abstract}
One of the Covid-19 pandemic real impacts in the community is the increase in the number of pregnancies. East Java, as one of the most populous provinces in Indonesia, has shown an increase in pregnancy rates during the pandemic. The rate of preterm births in East Java was 23.3\%. 885 babies were born in Surabaya with low birth weight (LBW) in 2018. Periodontal diseases are one of the risk factors for preterm birth and LBW. Gingivitis and periodontitis are commonly found during pregnancy. In Surabaya, a study conducted at eight health centers showed $73 \%$ of pregnant women had gingivitis and $36 \%$ had periodontitis. Our community service focus on periodontal and oral health for pregnant women. The target of this community service is pregnant women who carry out pregnancy control at the main clinic in the Tambak Sari sub-district. The program is carried out through video playback methods, lectures, discussions, and demonstrations of periodontal and oral health procedures. The program success indicator is score improvement through pre and posttest. Through this community service, knowledge and conscious behavior of periodontal health for pregnant women can be improved. Thus, it is expected to reduce the risk of periodontal disease for pregnancy.
\end{abstract}

Keywords: gingivitis, periodontitis, periodontal tissue, pregnancy

\begin{abstract}
Abstrak.
Salah satu dampak nyata dari adanya pandemi Covid-19 dan kebijakan bekerja dari rumah adalah peningkatan angka kehamilan di masyarakat. Jawa Timur sebagai salah satu provinsi dengan jumlah penduduk terbanyak di Indonesia menunjukkan peningkatan angka kehamilan selama masa pandemi. Tingkat kelahiran prematur di Jawa Timur sebesar $23.3 \%$, sementara pada tahun 2018, 885 kelahiran bayi di Surabaya memiliki berat badan lahir rendah (BBLR). Salah satu faktor resiko dari kelahiran bayi prematur dan BBLR (berat badan lahir rendah) adalah adanya kelainan jaringan rongga mulut yaitu kelainan periodontal. Kelainan periodontal yang umum ditemukan pada ibu hamil diantaranya adalah gingivitis dan periodontitis. Di Kota Surabaya, studi yang dilakukan pada delapan puskesmas menunjukkan $73 \%$ ibu hamil mengalami gingivitis dan $36 \%$ ibu hamil mengalami periodontitis. Mengingat pentingnya kesehatan periodontal, gigi dan mulut selama masa kehamilan, pada pengabdian masyarakat kali ini dilakukan sosialisasi kesehatan jaringan periodontal, gigi dan mulut pada ibu hamil. Target sasaran dari pengabdian masyarakat ini adalah ibu hamil yang melakukan kontrol kehamilan pada klinik utamaarea kecamatan Tambak Sari. Pengabdian masyarakat dilakukan melalui metode pemutaran video, ceramah, diskusi dan peragaan prosedur kesehatan periodontal dan rongga mulut. Keberhasilan dari program pengabdian masyarakat ini dinilai melalui indikator peningkatan nilai pada tes tertulis yang diberikan sebelum dan sesudah pelaksanaan sosialisasi. Melalui pengabdian masyarakat ini, pengetahuan dan prilaku sadar periodontal sehat bagi ibu hamil dapat ditingkatkan, sehingga diharapkan dapat mengurangi resiko penyakit periodontal bagi kehamilan.
\end{abstract}

Kata Kunci: kehamilan, gingivitis, jaringan periodontal, periodontitis

\begin{tabular}{l|l|l} 
Submitted: 2020-09-22 & Revised: 2020-10-04 & Accepted: 2020-10-05
\end{tabular}




\section{Pendahuluan}

Organisasi Kesehatan Dunia (WHO) menetapkan peristiwa menyebarnya penyakit akibat virus corona-19 (Covid-19) sebagai pandemi Covid-19 pada tanggal 11 Maret 2020. Penyakit yang disebabkan oleh virus SARS-CoV-2 menyebar dengan cepat ke berbagai negara termasuk Indonesia. Indonesia mengumumkan kasus postir Covid-19 pertamanya pada tanggal 2 Maret 2020 dan semenjak itu hingga September 2020 jumlah kasus positif Covid-19 terus menunjukkan peningkatan. Adanya pandemi Covid-19, pemberlakuan pembatasan sosial berskala besar dan kebijakan bekerja dari rumah tidak hanya menimbulkan masalah kesehatan, melainkan juga ekonomi, sosial dan aspek lainnya (BKKBN Jatim, 2020).

Salah satu dampak nyata dari adanya pandemi Covid-19 dan kebijakan bekerja dari rumah adalah peningkatan angka kehamilan di masyarakat. Jawa Timur sebagai salah satu provinsi dengan jumlah penduduk terbanyak di Indonesia menunjukkan peningkatan angka kehamilan selama masa pandemi. Tingkat kehamilan di Jawa Timur dalam masa pandemi di Bulan Februari 229.667 (2,84 \% dari total pasangan usia subur (PUS)) mengalami peningkatan di Bulan Maret yaitu 232.287 (2,93\%). Jumlah PUS di Jawa Timur pada data statistik rutin April 2020 tercatat sebanyak 7.849.073. Sebagian dari PUS ini tidak terlindungi/tidak memakai alat kontrasepsi (BKKBN Jatim, 2020).

Peningkatan angka kehamilan dalam kondisi pandemi akan mengakibatkan peningkatan jumlah penduduk di masa yang akan datang yang dapat menimbulkan beban baru bagi negara. Namun selain upaya-upaya untuk mencegah atau mengurangi peningkatan angka kehamilan, penting juga untuk dilakukan upaya peningkatan kesehatan bagi ibu yang sedang hamil di masa pandemi karena angka komplikasi kehamilan di Indonesia masih cukup tinggi. Proporsi komplikasi kehamilan pada perempuan usia 10-54 tahun di Indonesia adalah 28\%, sementara itu tingkat kelahiran prematur di Jawa Timur sebesar 23.3\% (Riset Kesehatan Dasar, 2018). Pada tahun 2018, 885 kelahiran bayi di Surabaya memiliki berat badan lahir rendah (BBLR) (BPS Jatim, 2019).

Salah satu faktor resiko dari kelahiran bayi prematur dan BBLR adalah adanya kelainan jaringan rongga mulut yaitu kelainan periodontal (Thakur et al., 2020; Vidhale et al., 2020; Wijaksana, 2019). Kelaianan periodontal yang umum ditemukan pada ibu hamil diantaranya adalah gingivitis dan periodontitis. Di Kota Surabaya, studi yang dilakukan pada delapan puskesmas menunjukkan $73 \%$ ibu hamil mengalami gingivitis dan $36 \%$ ibu hamil mengalami periodontitis (Tedjosasongko et al., 2019). Wanita dengan periodontitis generalis beresiko 5 kali lebih besar mengalami kelahiran prematur sebelum usia kehamilan 35 minggu dan 7 kali lebih besar dalam usia kehamilan kurang dari 32 minggu. Periodontitis lebih mampu mempengaruhi hasil kehamilan dibanding kebiasaan merokok maupun konsumsi alkohol saat kehamilan (Klokkevold \& Mealey, 2019).

Data Tahun 2015-2019 Kota Surabaya menunjukkan Kecamatan Tambaksari memiliki tingkat kelahiran bayi tertinggi. Pada tahun 2019, angka kelahiran di kecamatan ini tercatat 2.492, atau sekitar 7,6\% dari angka kelahiran di Surabaya pada tahun 2019 (32.585) (BPS Surabaya, 2020). Berdasarkan data diatas, maka pengabdian masyarakat dilakukan di salah satu klinik utama pada Kecamatan Tambak Sari dengan kunjungan ibu hamil yang cukup tinggi. Melalui pengabdian masyarakat ini diharapkan terjadi 
peningkatan pengetahuan dan prilaku sadar periodontal sehat bagi ibu hamil, sehingga dapat mengurangi resiko penyakit periodontal bagi kehamilan.

\section{Metode}

Pengabdian masyarakat dilakukan melalui 2 tahapan, yaitu pengumpulan data lapangan dan sosialisasi lapangan. Pengumpulan data lapangan dilakukan melalui metode kuisioner. Pada tahap kedua dilakukan sosialisasi melalui penayangan video, penyampaian materi, diskusi dan tanya jawab serta simulasi cara menjaga kesehatan rongga mulut yang benar dalam masa kehamilan. Target sasaran dari pengabdian masyarakat ini adalah ibu hamil yang melakukan kontrol kehamilan pada klinik utama. Keberhasilan dari program pengabdian masyarakat ini dinilai melalui indikator peningkatan nilai pada tes tertulis yang diberikan sebelum dan sesudah pelaksanaan sosialisasi. Analisa indikator dilakukan melalui uji komparatif 2 kelompok berpasangan dengan tingkat kepercayaan $95 \%$ yang diolah dengan IBM SPPS 21 . Ketrampilan ibu hamil dalam melakukan prosedur kebersihan rongga mulut dinilai melalui pengamatan peserta sosialisasi mampu memperagakan prosedur kebersihan rongga mulut mandiri dengan tepat.

\section{Hasil dan Pembahasan}

Pelayanan kesehatan gigi dan mulut ibu hamil merupakan pelayanan kesehatan yang ditujukan kepada janin yang dikandung dan juga ibu hamil. Pelayanan kesehatan gigi dan mulut yang ditujukan kepada janin yang dikandung diberikan dalam rangka mengoptimalkan tumbuh kembang janin dan mencegah terjadinya kelainan kongenital tubuh khususnya dento-orofacial. Pelayanan kesehatan gigi dan mulut yang ditujukan pada ibu hamil diberikan untuk memelihara dan meningkatkan kesehatan gigi dan mulut ibu hamil dalam rangka membantu mengoptimalkan kesehatan ibu secara keseluruhan demi tumbuh kembang janin yang baik (Permenkes No. 89, 2015).

Dalam masa pandemi Covid-19, peningkatan pengetahuan, ketrampilan dan kemandirian ibu hamil dalam perawatan rongga mulut, gigi dan jaringan periodontal menjadi lebih penting mengingat dalam suasana pandemi banyak praktik dokter gigi yang tidak berpraktik akibat tingginya resiko penularan Covid-19 melalui aerosol dalam prosedur perawatan rongga mulut. Melalui sosialiasi kesehatan gigi dan mulut khususnya jaringan periodontal, diharapkan terjadi peningkatan pengetahuan pentingnya perawatan gigi dan mulut khususnya jaringan periodontal bagi ilmu hamil dan peningkatan ketrampilan ibu hamil dalam mendeteksi gejala awal kelainan periodontal pada kehamilan serta peningkatan ketrampilan ibu hamil dalam melakukan prosedur kebersihan rongga mulut secara mandiri di rumah.

Pada pengabdian masyarakat ini, setiap ibu hamil diberikan kit mandiri yang berisikan buku panduan pemeliharaan kesehatan jaringan periodontal, gigi dan mulut selama kehamilan; set alat pemeriksaan rongga mulut sederhana, sikat gigi dan pasta gigi, buku catatan dan alat tulis (Gambar 1). Pelaksanaan pengabdian masyarakat dilakukan dengan tetap memperhatikan protokol kesehatan dimasa pandemi korona. Materi penyuluhan disampaikan oleh Lambang Bargowo drg., M.Kes., Sp.Perio(K) (Gambar 2). 

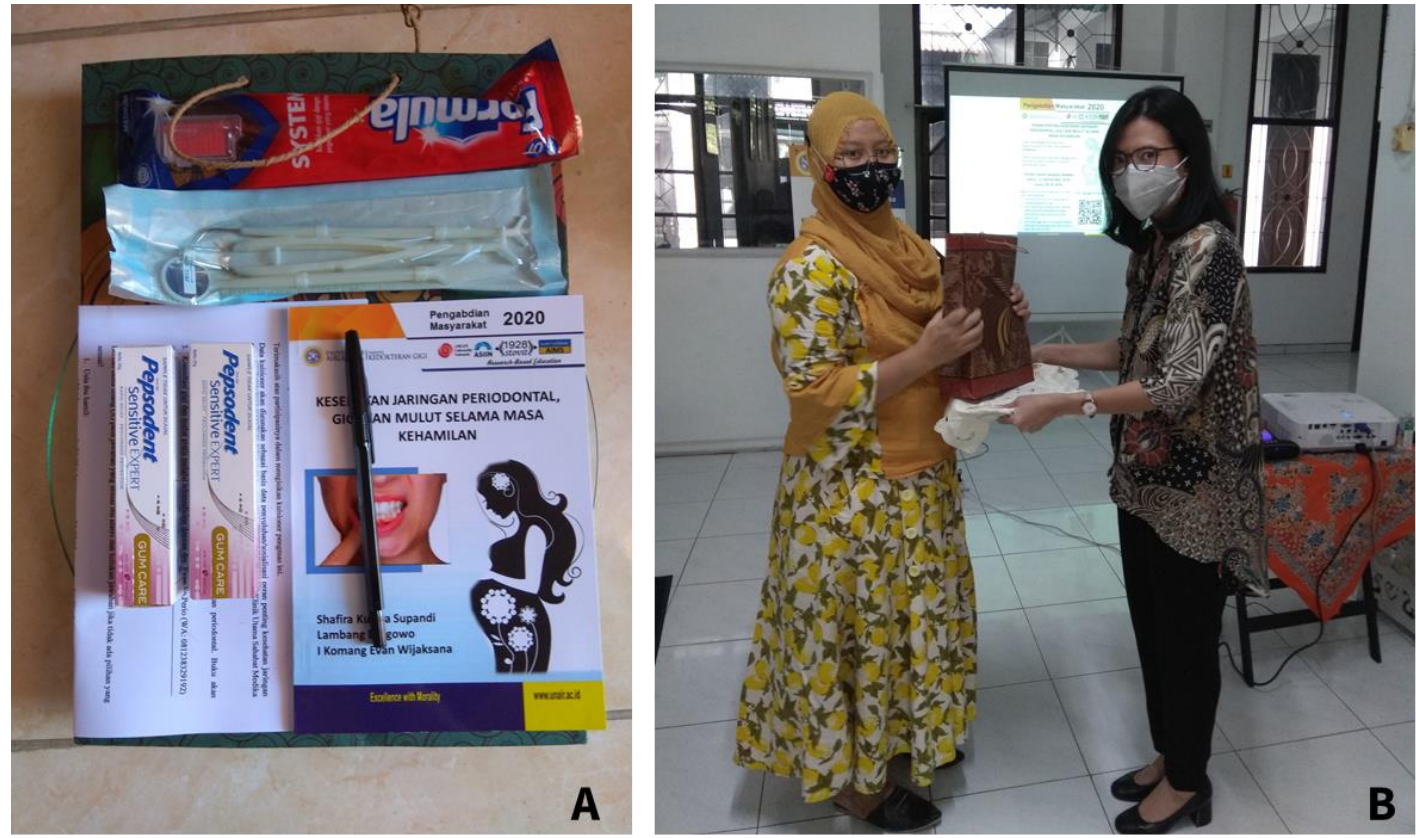

Gambar 1. Kit mandiri bagi ibu hamil (A) dan penyerahan secara simbolis kepada ibu hamil (B).
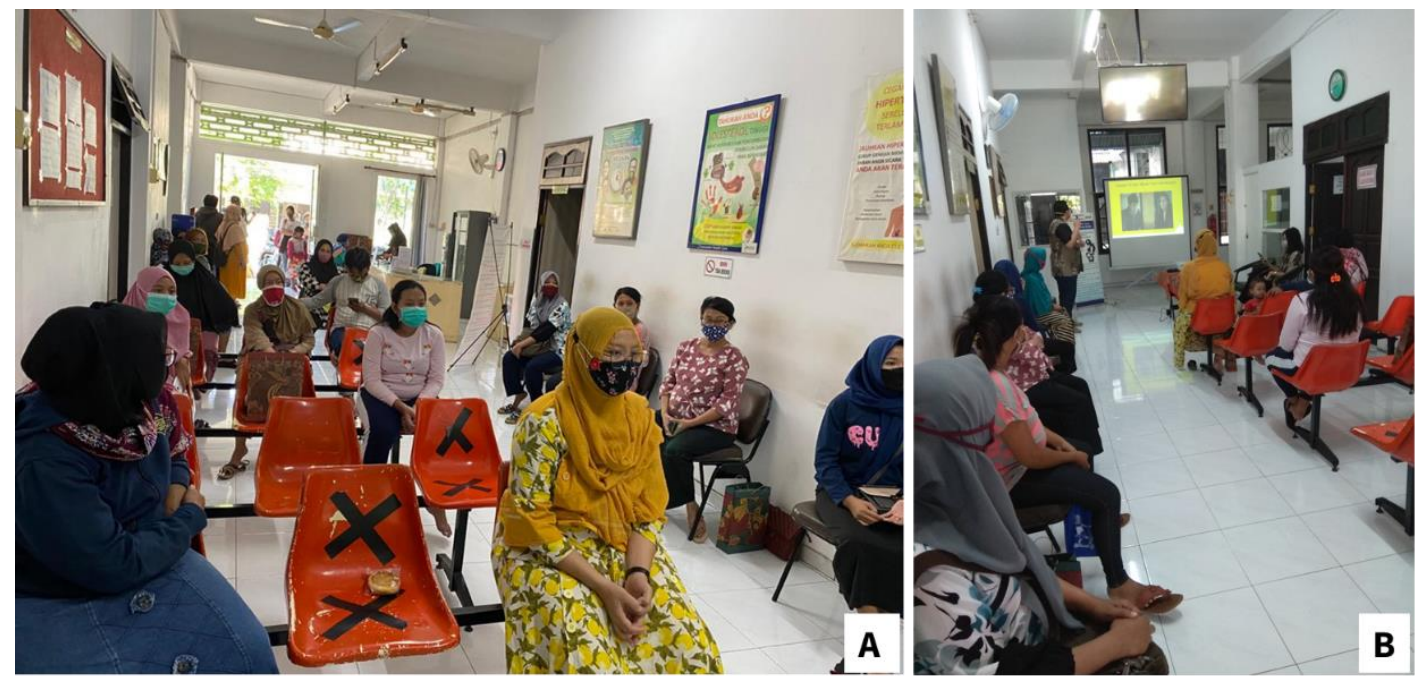

Gambar 2. Suasana pelaksanaan sosialisasi dengan protokol kesehatan(A) dan penyampaian materi oleh tim pengmas (B).

Pada pengabdian masyarakat ini, didapatkan data karakteristik ibu hamil yang melakukan kontrol kehamilan pada lokasi pengabdian masyarakat (tabel 1). Berdasarkan data dapat diketahui bahwa peserta pengabdian masyarakat kali ini terdiri dari ibu hamil yang sebagian besar (55.26\%) memiliki usia 21-30 tahun. 36.84 persen dari Ibu hamil tersebut memiliki kehamilan pertama. Mayoritas $(57.89 \%)$ dari ibu hamil memiliki pendidikan akhir Sekolah Menengah Atas (SMA). 
Tabel 1. Karakteristik ibu hamil peserta sosialisasi

\begin{tabular}{|c|c|c|c|}
\hline Karakteristik & Kategori & Jumlah & Persentase \\
\hline Ibu Hamil & & 38 & 100 \\
\hline \multirow{4}{*}{ Usia } & $\leq 20$ tahun & 4 & 10.53 \\
\hline & 21-30 tahun & 21 & 55.26 \\
\hline & $31-40$ tahun & 12 & 31.58 \\
\hline & $>40$ tahun & 3 & 2.63 \\
\hline \multirow{3}{*}{ Trimester Kandungan } & 1 & 11 & 28.95 \\
\hline & 2 & 12 & 31.58 \\
\hline & 3 & 15 & 39.47 \\
\hline \multirow{3}{*}{ Kehamilan ke- } & 1 & 14 & 36.84 \\
\hline & 2 & 11 & 28.95 \\
\hline & $\geq 3$ & 13 & 34.21 \\
\hline \multirow{4}{*}{ Pendidikan } & SD & 6 & 15.79 \\
\hline & SMP & 2 & 5.26 \\
\hline & SMA & 22 & 57.89 \\
\hline & Diploma/Sarjana & 8 & 21.05 \\
\hline \multirow{4}{*}{ Kontrol ke dokter kandungan } & 1x sebulan & 28 & 73.68 \\
\hline & $2 x$ sebulan & 4 & 10.53 \\
\hline & $1 x$ dalam 2 bulan & 4 & 10.53 \\
\hline & Lainnya & 2 & 5.26 \\
\hline \multirow{2}{*}{$\begin{array}{l}\text { Memiliki keluhan gigi dan } \\
\text { mulut selama kehamilan }\end{array}$} & Ya & 10 & 26.32 \\
\hline & Tidak & 28 & 73.68 \\
\hline \multirow{4}{*}{$\begin{array}{l}\text { Frekuensi ke drg selama } \\
\text { kehamilan }\end{array}$} & 0 & 31 & 81.58 \\
\hline & 1 & 3 & 7.89 \\
\hline & 2 & 1 & 2.63 \\
\hline & $\geq 3$ & 3 & 7.89 \\
\hline \multirow{2}{*}{$\begin{array}{ll}\text { Penilaian keamananan ke } \\
\text { drg selama kehamilan }\end{array}$} & Aman & 29 & 76.32 \\
\hline & Tidak Aman & 9 & 23.68 \\
\hline
\end{tabular}

Pada pengabdian masyarakat ini, didapati data bahwa $73.68 \%$ ibu hamil yang merasa tidak memiliki keluhan terhadap rongga mulutnya selama kehamilan. Dari 38 ibu hamil, hanya 10 ibu yang merasa memiliki keluhan terkait rongga mulutnya. Namun dari 10 ibu yang memiliki keluhan rongga mulut selama kehamilan, hanya 3 ibu yang melakukan perawatan rongga mulutnya ke dokter gigi, meskipun kesepuluh ibu hamil tersebut menyatakan aman melakukan perawatan ke dokter gigi selama masa kehamilan. Keluhan gigi mulut yang dirasakan oleh ibu hamil diantaranya gusi berdarah (5 orang), gigi goyang ( 1 orang) dan nyeri akibat gigi berlubang (4 orang). Selama masa kehamilan, perubahan hormonal menyebabkan peningkatan respon keradangan dalam rongga mulut. Selama masa kehamilan, cairan sulkus gingiva akan mengalami peningkatan, begitu juga dengan kegoyangan dari gigi. Umumnya gingivitis akan mulai meningkat selama masa kehamilan bulan kedua hingga ketiga (Klokkevold \& Mealey, 2019). Mayoritas ibu hamil tidak memiliki keluhan gigi dan mulut selama masa kehamilan dapat juga diakibatkan oleh kurang perhatiannya ibu hamil terhadap tanda-tanda awal dari masalah rongga mulut (Meqa et al., 2017). Oleh karena itu dalam pengabdian masyarakat ini ditekankan juga pada ibu hamil untuk dapat mengerti tanda dan gejala awal yang umum muncul pada masa kehamilan, sehingga efek negatif jangka panjang pada ibu hamil maupun janin dapat dihindari. 
Mayoritas ibu hamil belum memeriksakan kondisi rongga mulutnya selama kehamilan, baik karena memiliki keluhan maupun tidak. Hal ini tentunya berbanding terbalik dengan keteraturan ibu hamil untuk melakukan kontrol kehamilannya, dimana mayoritas ibu hamil melakukan kontrol kehamilan minimal 1 kali dalam 1 bulan. Kondisi ini selaras dengan data nasional yang menunjukkan 95,4\% ibu hamil rutin memeriksakan kandungannya selama masa kehamilan (Riset Kesehatan Dasar, 2013). Namun belum ada data nasional yang menunjukkan tingkat kunjungan rutin ibu hamil untuk kontrol kesehatan gigi dan mulut selama masa kehamilan. Dalam hal ini, sinergi antara tenaga medis kehamilan dan gigi dan mulut perlu untuk ditingkatkan guna dapat menjaga dan meningkatan kesehatan ibu dan janin sejak dini secara menyeluruh.

23.68\% ibu hamil menyatakan bahwa memeriksakan gigi dan mulut selama kehamilan tidaklah aman. Data ini menunjukkan bahwa edukasi kesehatan dan perawatan gigi dan mulut pada ibu hamil perlu untuk ditingkatkan. Melalui pengabdian masyarakat ini, pengetahuan dan ketrampilan ibu hamil dapat di tingkatkan. Uji statistik Wilcoxon melalui tes sebelum dan sesudah penyampaian materi menunjukkan adanya peningkatan pengetahuan $(p<0.05)$ dari ibu hamil peserta pengabdian masyarakat (tabel 2 ). Kemampuan ibu hamil dalam memperagakan prosedur menjaga kebersihan rongga mulut dengan alat bahan dan cara yang benar menunjukkan peningkatan ketrampilan ibu hamil.

Tabel 2. Hasil penilaian pengetahuan melalui pretest dan posttest pada ibu hamil

\begin{tabular}{ccccc}
\hline Tes & Jumlah & $\begin{array}{c}\text { Median } \\
(\text { Min-Max })\end{array}$ & $\begin{array}{c}\text { Shapiro-Wilk } \\
(\text { Sig. })\end{array}$ & $\begin{array}{c}\text { Uji } \\
\text { Nilcoxon (Sig.) }\end{array}$ \\
\cline { 1 - 4 } Nilai pretest & 38 & $\begin{array}{c}50 \\
(40-60)\end{array}$ & 0.000 & 0.000 \\
\cline { 1 - 4 } Nilai posttest & 38 & $\begin{array}{c}80 \\
(70-100)\end{array}$ & 0.000 & \\
\hline
\end{tabular}

Sebagai upaya mempersiapkan generasi emas Indonesia, maka setiap calon generasi penerus bangsa hendaknya mendapatkan kesehatan optimal sejak dalam masa kandungan. Sinergi antar tenaga kesehatan terkait kehamilan dan kesehatan rongga mulut diperlukan untuk dapat memberikan kesehatan yang menyeluruh baik bagi ibu hamil maupun sang buah hati. Kedepan, program-program pengabdian masyarakat terkait kesehatan gigi dan mulut perlu digencarkan dengan melibatkan lebih banyak pihak terkait seperti puskesmas, bidan, dokter gigi, dokter kandungan serta kader-kader kesehatan yang ada di masyarakat.

\section{Kesimpulan}

Dalam pengabdian masyarakat ini, pengetahuan dan ketrampilan ibu hamil terkait kesehatan jarringan periodontal, gigi dan mulut selama masa kehamilan dapat di tingkatkan dan diharapkan dapat mengurangi resiko penyakit periodontal bagi kehamilan. Dengan melakukan pengabdian masyarakat dengan target secara langsung kepada ibu hamil, informasi penting bagi ibu hamil dapat lebih mudah disampaikan, dan bekerja sama dengan klinik kesehatan dalam pengabdian masyarakat mempermudah lokasi dan koordinasi dalam melakukan pengabdian masyarakat. Pengabdian masyarakat ini akan lebih baik jika disertai dengan pemeriksaan rongga mulut ibu hamil secara langsung. 
Namun mengingat potensi penyebaran virus corona dalam masa pandemi, kegiatan pemeriksaan langsung dapat dilakukan sebagai pengembangan pada pengabdian masyarakat berikutnya. Pengembangan di masa yang akan datang dapat dilakukan pula sosialisasi pada ibu hamil beserta suami, mengingat peran penting suami agar dapat mengingatkan dan membantu istri dalam menjaga kesehatan rongga mulut selama kehamilan. Program pengabdian masyarakat ini juga perlu digencarkan dengan melibatkan lebih banyak pihak terkait seperti puskesmas, bidan, dan dokter kandungan serta kader-kader kesehatan yang ada di masyarakat.

\section{Daftar Pustaka}

BKKBN Jatim. 2020. Dampak Covid-19, Banyak Warga Tak Pakai Alat Kontrasepsi. Artikel BKKBN Jatim. Diakses pada http://jatim.bkkbn.go.id/category/artikel/

BPS Jatim. 2019. Jumlah Bayi Lahir, Bayi Berat Badan Lahir Rendah (BBLR), dan Bergizi Kurang di Provinsi Jawa Timur Menurut Kabupaten Kota Tahun 2018. Diakses pada https://jatim.bps.go.id/statictable/2019/10/09/1675/jumlah-bayi-lahir-bayi-beratbadan-lahir-rendah-bblr-dan-bergizi-kurang-di-provinsi-jawa-timur-menurutkabupaten-kota-2018-.html

BPS Surabaya. 2020. Kota Surabaya Dalam Angka 2020. Surabaya: CV. Azka Putra Pratama.

Klokkevold PR, \& Mealey BL. 2019. Impact of Periodontal Infection on Systemic Health. In Newman MG, Takei HH, Klokkevold PR, \& Carranza FA (Eds.), Newman and Carranza's Clinical Periodontology Ed. 13th. Philadelphia: Elsevier, Inc. p.208

Meqa K, Dragidella F, Disha M, Sllamniku-Dalipi Z. 2017. The Association between Periodontal Disease and Preterm Low Birthweight in Kosovo. Acta Stomatologica Croatica, 51(1), 33-40. https://doi.org/10.15644/asc51/1/4

Peraturan Menteri Kesehatan Republik Indonesia nomor 89 Tahun 2015 tentang Upaya Kesehatan Gigi dan Mulut. p.5-6.

Riset Kesehatan Dasar. 2013. Badan Penelitian dan Pengembangan Kesehatan Departemen Kesehatan Republik Indonesia.

Riset Kesehatan Dasar. 2018. Badan Penelitian dan Pengembangan Kesehatan Departemen Kesehatan Republik Indonesia.

Tedjosasongko U, Anggraeni F, Wen ML, Kuntari S, Puteri MM. 2019. Prevalence of Caries and Periodontal Disease Among Indonesian Pregnant Women. Pesquisa Brasileira Em Odontopediatria e Clinica Integrada, 19, e4533. https://doi.org/10.4034/pboci.2019. 191.90

Thakur RK, Yadav BK, Sultana R, et al. 2020. Influence of periodontal infection as a possible risk factor for preterm low birth weight. Journal of Pharmacy And Bioallied Sciences, 12(5), 613-618. https://doi.org/10.4103/jpbs.JPBS_73_20

Vidhale P, Puri S, Bhongade ML. 2020. A relationship between maternal periodontal disease and preterm low birth weight: A cross-sectional study. Clinical Epidemiology and Global Health, in press. Diakses pada Https://doi.org/10.1016/j.cegh.2020. 04.007

Wijaksana IKE. 2019. Dental Treatment Consideration in Pregnant Women. Jurnal Kesehatan Gigi, 6(2), 118-125. https://doi.org/10.31983/jkg.v6i2.5488 